\title{
Heat Dissipation Mechanism for Magnetite Nanoparticle in Magnetic Fluid Hyperthermia
}

\author{
M. Suto, Y. Hirota*, H. Mamiya**, R. Kasuya, A. Fujita ${ }^{* * *}$, K. Tohji, and B. Jeyadevan \\ Graduate School of Environmental Studies, Tohoku Univ., Aoba 6-6-20, Aramaki, Aoba-ku, Sendai, 980-8579, Japan \\ *Ferrotec Co., 1-4 Midoridaira, Sosa, 289-2131, Japan \\ **Nanomaterials Laboratory, National Institute for Materials Science, 1-2-1 Sengen, Tsukuba 305-0047, Japan \\ $* * *$ Department of Materials Science, Graduate School of Engineering, Tohoku Univ., \\ Aoba 6-6-02, Aramaki, Aoba-ku, Sendai, 980-8579, Japan
}

\begin{abstract}
We report the results of a study undertaken to determine properties of magnetite particles that dissipate heat only through Néel relaxation. The magnetite samples we considered for the heat dissipation studies were found to dissipate heat through both Néel and Brownian relaxations. The relative contributions of both relaxations on magnetic heat dissipation were investigated by analyzing the physical, magnetic, and heating characteristics of magnetite particles with various average diameters dispersed in low and high viscosity media. The results suggested that the size of magnetite particles that dissipated heat through Néel relaxation was around $12 \mathrm{~nm}$ and this agreed well with theoretical predictions.
\end{abstract}

Key words: Heat dissipation, Néel relaxation, Brownian relaxation, magnetite, magnetic fluid

\section{磁性流体癌温熱療法のための マグネタイトナノ粒子の発熱機構の検討}

須藤誠・廣田泰丈*・間宮広明*** 粕谷亮・藤田麻哉*** ・田路和幸・バラチャンドラン ジャヤデワン

東北大学大学院環境科学研究科, 宮城県仙台市青葉区荒巻字青葉 6-6-20（†982-8579）

*株式会社フェローテック，千葉県匝瑳市みどり平 1-4（テ289-2131）

**物質・材料研究機構ナノマテリアル研究所，茨城県つくば市千現 1-2-1（テ 305-0047）

***東北大学大学院工学研究科, 宮城県仙台市青葉区荒巻字青葉 6-6-02（广980-8579）

\section{1. 序論}

現在, 癌は外科療法, 化学療法, 放射線療法かまたはそ れらを組み合わせて治療されている。しかしながら，上記 の治療法は患者への身体的および精神的な負担が大きいた め, より低侵襲な治療法が検討されている. その治療法の 一つとして，磁性ナノ粒子の発熱によって癌組織を治療す る磁性流体癌温熱療法 (Magnetic Fluid Hyperthermia: $\mathrm{MFH})$ が近年注目されている ${ }^{1,2)}$. 癌細胞の増殖に伴い, 組織内の血管は毛細化するため血流の熱散逸効果が減少す る. MFH とは, 癌組織が熱を蓄えやすいことを利用して, 癌組織へ導入した磁性ナノ粒子の磁気発熱により局所的に $43{ }^{\circ} \mathrm{C}$ 程度に加温して治療する方法である. MFH には蓄熱 による細胞の壊死に加えて, 熱輸送能力の高い正常細胞が 適度に加温されることで免疫能力が元進する効果も報告さ れている ${ }^{3)}$.

近年の磁性ナノ粒子の合成技術の進展により，MFH に 適したさまざまな磁性ナノ粒子が検討されている ${ }^{4,5)}$. そ の中でも, マグネタイト $\left(\mathrm{Fe}_{3} \mathrm{O}_{4}\right)$ は高い生体適合性を有 していることに加えて，粒子合成が簡便であること，そし て平均粒子径の制御が容易であることから最適であると考 えられている ${ }^{6,7)}$. これまで, 粒子径の異なる $\mathrm{Fe}_{3} \mathrm{O}_{4}$ ナノ 粒子に交流磁場を印加し, 発熱特性を評価する試みが数多 く行われてきた ${ }^{8)}$ １2）。

磁性ナノ粒子は粒子径によって発熱機構が異なり, $\mathrm{Fe}_{3} \mathrm{O}_{4}$ を例にとると, 直径 $40 \mathrm{~nm}$ 以上では多磁区構造を有 し磁気ヒステリシス損失により発熱する一方，それより小 さくなると単磁区構造をもつようになり, 粒子自身の回転
(Brown 緩和機構) によって磁気エネルギーを吸収して発 熱する. また, 粒子径が十数 $\mathrm{nm}$ 程度にまで小さくなると, 今度は粒子内部の磁気モーメントの回転（Néel 緩和機構） により磁気エネルギーを吸収して発熱する。磁気緩和によ る温熱実験に用いられている $\mathrm{Fe}_{3} \mathrm{O}_{4}$ ナノ粒子は, Néel 緩和 および Brown 緩和機構による磁気モーメントの緩和の遅 れにより発熱する。その磁気モーメントの緩和による発熱 特性は理論的に計算されており ${ }^{13)}$, さまざまな粒子の発熱 量に関する実験的検討がされてきた. しかしながら, $\mathrm{Fe}_{3} \mathrm{O}_{4}$ ナノ粒子の発熱量に対する各々の緩和機構の寄与は，十分 には検討されていない. それに加えて，各サンプルのポテ ンシャルを表す比吸収率 (Specific Absorption Rate: SAR) の単位, W/g には, それを左右する周波数や磁場強度を含 んでいない。このため過去の研究成果の単純な比較は困難 であり，最適な粒子を決定するために比較可能な単位が求 められている.

$\mathrm{Fe}_{3} \mathrm{O}_{4}$ ナノ粒子を $\mathrm{MFH}$ で用いるためには, in vitro と in vivo の両方で発熱特性が維持できることが重要である.

Brown 緩和は粒子の回転によって磁気モーメントが緩和 するため, その緩和時間は粒子の回転が束縛される高粘度 の環境では長くなる。一方, Néel 緩和は粒子内部の磁気モ 一メントの回転に由来するため, 粒子の回転自由度とは関 係なく発熱を生じる. 以上のことから, Néel 緩和によって 発熱する $\mathrm{Fe}_{3} \mathrm{O}_{4}$ ナノ粒子を生体組織へ導入することで，粘 度が一定しない生体環境中であっても発熱特性を維持でき ることが期待される. そこで本研究では, $\mathrm{Fe}_{3} \mathrm{O}_{4}$ ナノ粒子の 粒子特性や磁気特性を評価するとともに, 粘度の異なる媒 体に $\mathrm{Fe}_{3} \mathrm{O}_{4}$ ナノ粒子を分散させて発熱特性を測定し, 得ら 
れた結果を緩和機構の観点から検討した。また，サンプル の発熱特性を印加する交流磁場の周波数，および磁場強度 を考慮した比吸収率を提唱し，それを用いて評価した。

\section{2. 発熱機構}

磁性ナノ粒子の磁気発熱は, 印加する交流磁場に対する 磁気モーメントの緩和の遅れに起因し, その発熱量 $P$ は式 (1)で表される ${ }^{13}$.

$$
\begin{aligned}
& P=\mu_{0} \chi^{\prime \prime} f H_{\text {apply }}^{2} . \\
& \chi^{\prime \prime}=\frac{\omega \tau^{*}}{1+\left(\omega \tau^{*}\right)^{2}} \chi_{0} .
\end{aligned}
$$

ここで $P$ は発熱量 $\left[\mathrm{J} / \mathrm{m}^{3} \mathrm{~s}\right] ， \mu_{0}$ は真空の透磁率， $\chi^{\prime \prime}$ は交 流磁化率の虚部, $f$ は交流磁場の周波数, $H_{\text {apply }}$ は交流磁場 の磁場強度， $\tau^{*}$ は実効緩和時間， $\omega$ は角周波数， $\chi_{0}$ は実磁 化率をそれぞれ意味する.

式(1)の $\chi^{\prime \prime}$ は印加磁場に対する磁化の遅れを表しており, 式(2)で表される。これより $\chi^{\prime \prime}$ は $\tau^{*}$ が長いほど小さくなる ことがわかる。また， $\tau^{*}$ は Néel 緩和時間と Brown 緩和時 間の調和平均であり，式(3)のように書ける.

$$
\begin{aligned}
\tau^{*} & =\frac{\tau_{\mathrm{B}} \tau_{\mathrm{N}}}{\tau_{\mathrm{B}}+\tau_{\mathrm{N}}} . \\
\tau_{\mathrm{N}} & =\tau_{0} \exp \frac{K V_{\mathrm{M}}}{k T} . \\
\tau_{\mathrm{B}} & =\frac{3 \eta V_{\mathrm{H}}}{k T} .
\end{aligned}
$$

ここで $\tau_{\mathrm{N}}$ は Néel 緩和時間, $\tau_{\mathrm{B}}$ は Brown 緩和時間, $\tau_{0}=$ $10^{-9}\left[\mathrm{~s}\right.$ ] $K$ は異方性定数, $V_{\mathrm{M}}$ は粒子体積, $k$ は Boltzmann 定数, $T$ は温度, $\eta$ は粘度, $V_{\mathrm{H}}$ は流体力学的体積をそれぞれ 意味する.

式(4)，(5)より， $\tau_{\mathrm{N}}$ と $\tau_{\mathrm{B}}$ はいずれも粒子径が大きいほど 長くなる. 印加する交流磁場の 1 周期の時間 $(1 / f)$ が磁気 モーメントの実効緩和時間（ $\left.\tau^{*}\right)$ よりも小さくなる場合, 磁気モーメントの緩和に遅れが生じて磁気エネルギーが熱 エネルギーに変換される. 式(1)を用いて $\mathrm{Fe}_{3} \mathrm{O}_{4}$ ナノ粒子の

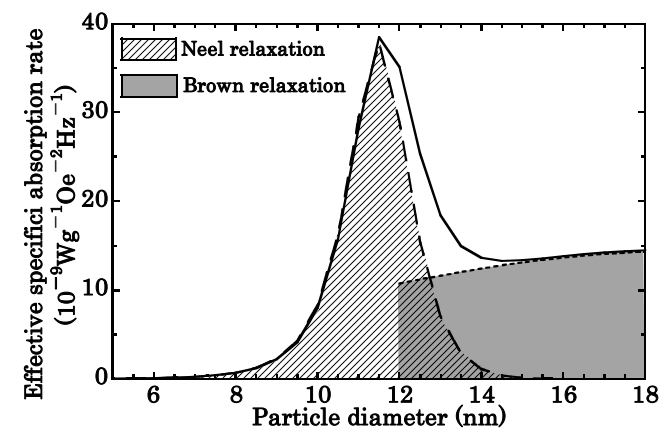

Fig. 1 Theoretical heat dissipation by Néel and Brownian relaxation in water. $f=600 \mathrm{kHz}$, $H_{\text {apply }}=3.2 \mathrm{kA} / \mathrm{m}, T=300 \mathrm{~K}, \eta=0.00089 \mathrm{~Pa} \cdot \mathrm{s}, M_{\mathrm{s}}$ $=446\left(\mathrm{kAm}^{-1}\right), K=30\left(\mathrm{kJm}^{-3}\right)$, specific heat $=670$ $\left(\mathrm{Jkg}^{-1} \mathrm{~K}^{-1}\right)$, density $=5180\left(\mathrm{kgm}^{-3}\right)$, concentration of $\mathrm{Fe}_{3} \mathrm{O}_{4}$ nanoparticles $=4.0$ (wt.\%)
理論発熱量を算出した結果を Fig. 1 に示寸. これより, 発 熱量だけでなく, Néel 緩和および Brown 緩和の相対的な 寄与も粒子径に左右されることがわかる.

また, 発熱量は印加磁場強度および周波数を考慮した実 効比吸収率 (Effective Specific Absorption Rate: ESAR) で 計算した. ESAR は式(6)で与えられる.

$$
E S A R=\frac{\sum_{i} c_{i} m_{i}}{m_{\mathrm{Fe}_{3} \mathrm{O}_{4}}} \frac{\Delta T}{\Delta t} \frac{1}{H_{\text {apply }}^{2} f} .
$$

ここで $c$ は比熱, $m_{i}$ は各物質の質量, $\mathrm{mFe}_{3} \mathrm{O}_{4}$ は $\mathrm{Fe}_{3} \mathrm{O}_{4}$ ナ ノ粒子の質量, $T$ は温度, $t$ は時間, $f$ は交流磁場の周波数, $H_{\text {apply }}$ は交流磁場の磁場強度, $\Delta T / \Delta t$ は $60 \mathrm{~s}$ あたりの温度 変化率をそれぞれ意味する。

\section{3. 実験}

\section{3. $1 \mathrm{Fe}_{3} \mathrm{O}_{4}$ ナノ 粒子分散試料の調製}

$\mathrm{Fe}_{3} \mathrm{O}_{4}$ ナノ粒子は共沈法によって合成した後, 異種溶媒 (アセトン等) を添加して沈降させた後にサイズ分級を行 (14), 粒子径の異なる 5 種類の粒子を得た。これをサンプ ル $\mathrm{A} \sim \mathrm{E}$ とし, 次にサンプル $\mathrm{A} \sim \mathrm{C}$ を油 (粘度約 $0.06 \mathrm{~Pa} \cdot \mathrm{s}$ ) 中に, サンプル D, E については水（粘度 $0.00089 \mathrm{~Pa} \cdot \mathrm{s} ）$ 中にそれぞれ分散させて低粘度サンプルを作製した。これ とは別に高粘度のサンプルを作製するため，低粘度サンプ ル $\mathrm{A} \sim \mathrm{C}$ には高分子を添加し, 粘度が約 $10 \mathrm{~Pa} \cdot \mathrm{s}$ となるよ う調整した。 一方, 水中に分散させた低粘度サンプル $\mathrm{D}, \mathrm{E}$ はポリビニルアルコール（PVA）ハイドロゲル中に分散さ せた。これらのサンプルを高粘度サンプルとした。なお， PVA ハイドロゲルは純水とジメチルスルホキシド（和光純 薬, $\min .99 \%$ ）を重量比 $6: 4$ の割合で混合し, $90{ }^{\circ} \mathrm{C}$ に 加温した後にPVA（日本酢ビ・ポバール社製 JF17）を 10 wt. \%の濃度となるように添加し, その後 $24 \mathrm{~h}$ 冷凍するこ とで調製した ${ }^{15)}$ 。文献 ${ }^{16)}$ によれば，10％PVAハイドロ ゲルの粘度は約 $5.9 \mathrm{~Pa} \cdot \mathrm{s}$ となる。 それぞれの粒子は界面活 性剤で表面を修飾することによって溶媒に分散させた。

\section{2 発熱特性評価}

各サンプルを試験管に $2 \mathrm{~mL}$ 注入してコイル中心に設置 し, 磁場強度 $40 \mathrm{Oe}$, 周波数 $600 \mathrm{kHz}$ の交流磁場を印加し て温度変化を測定した。温度測定には光ファイバー温度計 を用いた(Fig. 2). 得られた時間一温度曲線から式(6)を用い て ESAR を算出した。ここで, 水の比熱は $4.2 \mathrm{JK}^{-1} \mathrm{~g}^{-1}$ とし た ${ }^{17)}$.また, PVA ハイドロゲルの比熱, 低粘度の油分散媒 および高分子の比熱を示差走査熱量分析（DSC，Rigaku Thermo Plus 2 / DSC8230）を用いて測定したところ，そ れぞれ $2.76 \mathrm{JK}^{-1} \mathrm{~g}^{-1}, 2.3 \mathrm{JK}^{-1} \mathrm{~g}^{-1}, 1.83 \mathrm{JK}^{-1} \mathrm{~g}^{-1}$ と算出された.

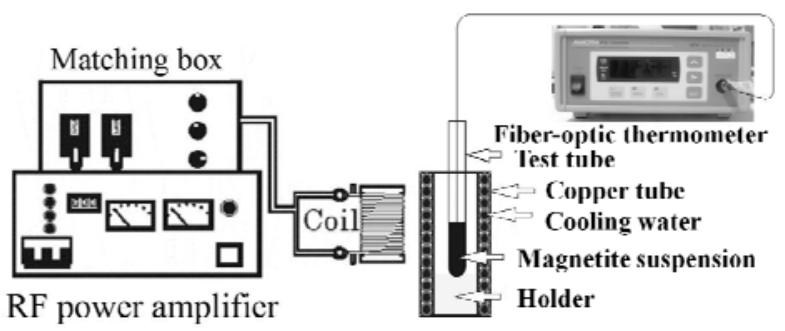

Fig. 2 Scheme of heat dissipation experiment. 
Table 1 Particulate properties and magnetic properties of prepared samples.

\begin{tabular}{|c|c|c|c|c|c|c|c|c|}
\hline \multirow{2}{*}{ Sample } & \multirow{2}{*}{$\begin{array}{c}\text { Average } \\
\text { diameter } \\
(\mathrm{nm})\end{array}$} & \multirow{2}{*}{$\begin{array}{l}\text { Standard } \\
\text { deviation } \\
\quad(\mathrm{nm})\end{array}$} & \multirow{2}{*}{$\begin{array}{l}\text { Crystallite } \\
\text { size }(\mathrm{nm})\end{array}$} & \multirow{2}{*}{$\begin{array}{c}\text { Blocking } \\
\text { temperature } \\
\text { at } 600 \mathrm{kHz} \\
(\mathrm{K})\end{array}$} & \multicolumn{4}{|c|}{$\begin{array}{l}\text { Effective specific absorption rate } \\
\qquad\left(10^{-9} \mathrm{Wg}^{-1} \mathrm{Oe}^{-2} \mathrm{~Hz}^{-1}\right)\end{array}$} \\
\hline & & & & & Water & $\begin{array}{l}\text { Water } \\
+ \text { PVA }\end{array}$ & Oil & $\begin{array}{c}\text { Oil } \\
+ \text { Polymer }\end{array}$ \\
\hline $\mathrm{A}$ & 10.0 & 2.3 & 8.8 & 64.1 & - & - & 0.8 & 0.8 \\
\hline B & 11.6 & 2.7 & 9.2 & 140.7 & - & - & 6.7 & 6.0 \\
\hline $\mathrm{C}$ & 13.9 & 3.4 & 11.0 & 220.9 & - & - & 16.4 & 15.8 \\
\hline $\mathrm{D}$ & 12.5 & 2.9 & 11.8 & 271.4 & 22.9 & 16.8 & - & - \\
\hline $\mathrm{E}$ & 15.7 & 4.4 & 13.2 & - & 29.5 & 9.7 & - & - \\
\hline
\end{tabular}
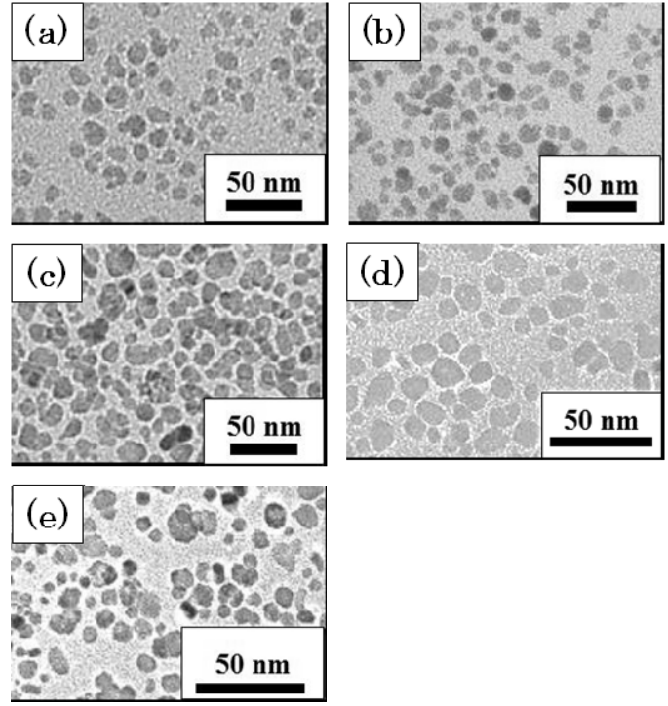

Fig. 3 TEM images of samples (a) A, (b) B, (c) C, (d) D, and (e) E.

\section{3 構造特性および粒子特性評価}

サンプルの結晶構造を粉末 X 線回折法 (XRD, Rigaku Multiflex）により同定した. 粒子の形態観察および微細構 造評価を透過型電子顕微鏡(FE-TEM，Hitachi，HF-2000) により評価した。サンプルの平均粒子径と標準偏差は, TEM 像から 400 個の粒子をランダムに選択し, その粒子 径を測定することで算出した。磁気特性は物理特性測定シ ステム(Physical Properties Measuring System, Quantum Design)により交流磁化率を評価した。サンプルの磁化 率曲線は, 印加する交流磁場の周波数を 10, 57, 320, 1788, $9977 \mathrm{~Hz}$ とそれぞれ変化させて，5 300 K の温度範囲で測 定した.

\section{4. 結果・考察}

\section{1 粒子特性および構造特性}

サンプル A E の TEM 像を Fig. 3 (a) ( e) にそれぞれ示す. また, TEM 像から算出したサンプルの平均粒子径, 標準偏 差を Table 1 に示す.これよりサンプルの平均粒子径は 10.0 15.7 nm の範囲内に分布している. 一方, XRD プロ ファイル(Fig. 4 (a) (e))で観測された回折ピークは, 全てス ピネル型構造を持つ $\mathrm{Fe}_{3} \mathrm{O}_{4}$ に帰属された.

XRD プロファイルから Scherrer の式を用いて結晶子径 を算出したところ，サンプル $\mathrm{A}<\mathrm{B}<\mathrm{C}<\mathrm{D}<\mathrm{E}$ の順に高 い值を示した。これは TEM 像から算出した平均粒子径の 傾向とよく一致したが, サンプル D の平均粒子径はサンプ ル C の值よりも大きい值となった。これは，XRD ではサ ンプルの広い範囲を観察するのに対して, TEM 観察では非

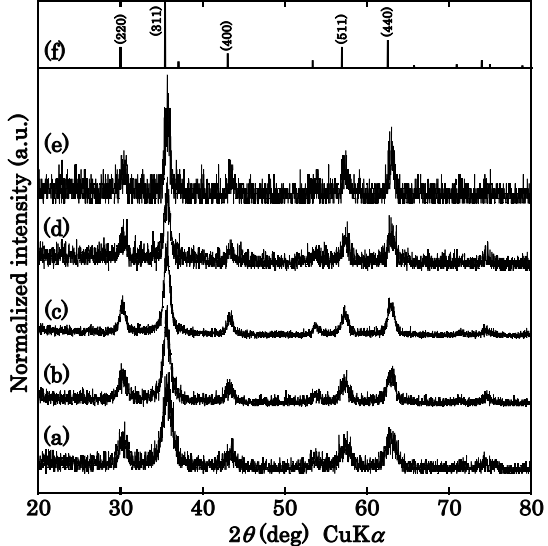

Fig. 4 XRD profiles for samples (a) A, (b) B, (c) C, (d) D, (e) E, and (f) JCPDS card data of $\mathrm{Fe}_{3} \mathrm{O}_{4}$ (No. 19-0629).

常に狭い視野の情報しか得られないことから，観察した粒 子に偏りがあったためと考えられる。そのため，XRD から 得られた結晶子径の方が粒子径を正確に反映していると考 えられる。そそこで，次に試料の平均粒子径をマクロな観点 から評価するために, 交流磁化率測定を行うこととした。

\section{2 磁気特性}

それぞれのサンプルの交流磁化率の虚部（ $\chi^{\prime \prime} ）$ を，温度 を横軸にとってプロットした(Fig. 5). サンプル A〜D では $\chi^{\prime \prime}$ が極大となる温度（平均ブロッキング温度： $T_{\mathrm{B}}$ ） が観測 され，周波数 $10 \mathrm{~Hz}$ における $T_{\mathrm{B}}$ はそれぞれ $30,80,120$, $205 \mathrm{~K}$ であった. 一方, サンプル $\mathrm{E}$ では $\chi^{\prime \prime}$ は加温に伴って 増大し，5 300 K の温度範囲では極大值を観測することは できなかった。これより，サンプル $\mathrm{E} の T_{\mathrm{B}}$ は $300 \mathrm{~K}$ 以上 であると考えられる。

$T_{\mathrm{B}}$ は $\mathrm{Fe}_{3} \mathrm{O}_{4}$ ナノ粒子の磁気緩和による発熱を磁気的に評 価しうる目安となる。TB以下の温度では, 磁気モーメント が磁化容易軸方向に束縛されており，交流磁場に追随でき ずに磁化率が低い值に留まる。これに対して，TB以上の温 度では熱摇らぎによって磁気モーメントがさまざまな方向 を向くため，磁化率は減少する。つまり，TBは交流磁場に 対して磁気モーメントの緩和が遅れ始める温度といえる.

式(4),(5)から，磁気モーメントの緩和時間はそれぞれ粒 子径が増大寸ると長くなる一方, 温度の上昇に伴って短く なる．そのため，ある周波数の磁場を印加した場合，大き い粒子ほど磁場の変化に対応できる温度，つまり $T_{\mathrm{B}}$ が高 くなる，このことから，粒子径はサンプル $\mathrm{A}<\mathrm{B}<\mathrm{C}<\mathrm{D}<$ $\mathrm{E}$ の順で大きいことが推察される. これは XRD 解析から 求めた結晶子径の傾向と一致した. TEM 像から算出した平 均粒子径とはサンプル C と D で異なった傾向を示したが, これは標準偏差が広いため誤差が生じたものと考えられる. 

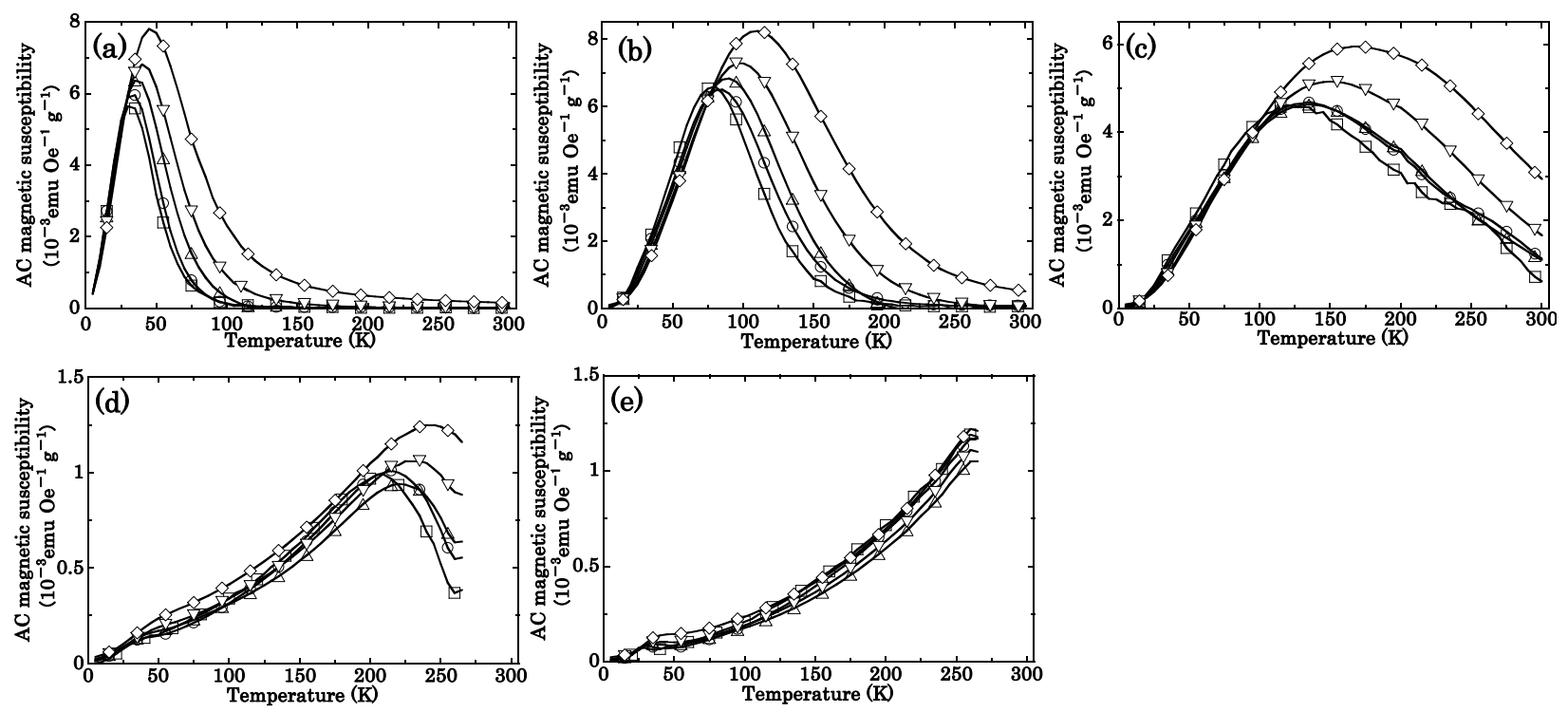

Fig. 5 Imaginary part of AC susceptibility ( $\left.\chi^{\prime \prime}\right)$ as function of temperature of samples (a) A, (b) B, (c) C, (d) D, and (e) E measured at various frequencies. $\square: 10 \mathrm{~Hz}, \bigcirc: 57 \mathrm{~Hz}, \triangle: 321 \mathrm{~Hz}, \nabla: 1788 \mathrm{~Hz}$, and $\diamond: 9977 \mathrm{~Hz}$.

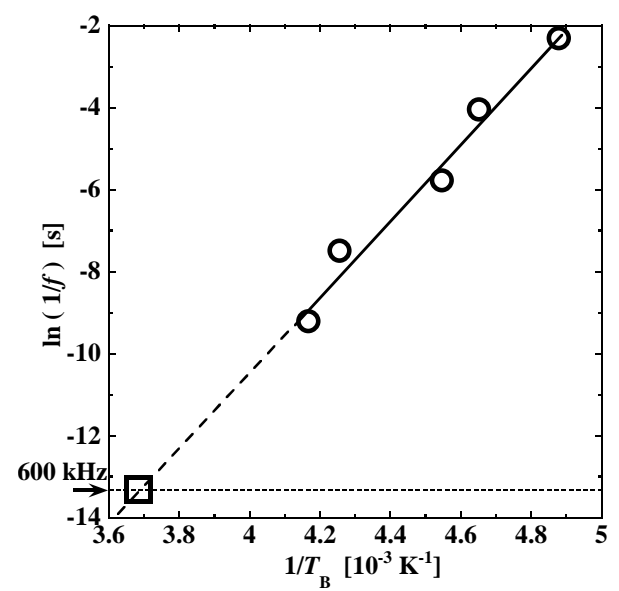

Fig. 6 Estimation of $T_{\mathrm{B}}$ for sample $\mathrm{D}$ at $600 \mathrm{kHz}$. $\bigcirc$ : Measured value, and $\square$ : predicted value.

また, 印加する周波数を増大させると $\mathrm{B}$ は高温側へシフ トした．本研究で作製した $\mathrm{Fe}_{3} \mathrm{O}_{4}$ ナノ粒子は単分散ではな く, 試料は異なった T⿱ 口 を持つ粒子で構成される.このため, $T_{\mathrm{B}}$ が周波数依存性を示したものと考えられる. 交流磁化率 の測定に用いた周波数は最大で $9977 \mathrm{~Hz}$ だったため, 600 $\mathrm{kHz}$ における $T_{\mathrm{B}}$ を実験的に求めることはできなかった. そのため, 10 から $9977 \mathrm{~Hz}$ における交流磁化率の測定結 果から， $600 \mathrm{kHz}$ における $T_{\mathrm{B}}$ を予測した。

ここで， $\mathrm{Fe}_{3} \mathrm{O}_{4}$ ナノ粒子同士が磁気的に相互作用し，磁 気モーメントの緩和時間が単独の粒子と比べて変化するこ とが懸念される。これについては，超常磁性粒子の粒子間 相互作用の磁気モーメントの緩和への影響は非常に小さい ことが実験により明らかにされている ${ }^{18)}$ 。そこで, 緩和時 間と $T_{\mathrm{B}}$ の関係 (式(4)) より，10 9977 Hz の範囲で測定 した $T_{\mathrm{B}}$ を交流磁場の周期 $(1 / f)$ に対してプロットした(Fig. 6). プロットから得られた近似直線を, 周波数 $600 \mathrm{kHz}$ に 相当する周期である $1.67 \times 10^{-6} \mathrm{~s}$ まで外挿した結果, サンプ ル A D の $T \mathrm{~B}$ はそれぞれ 64.1，140.7，220.9，271.4 K と

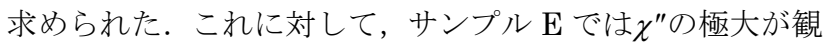

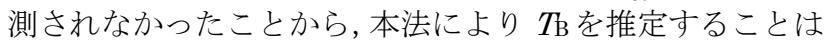

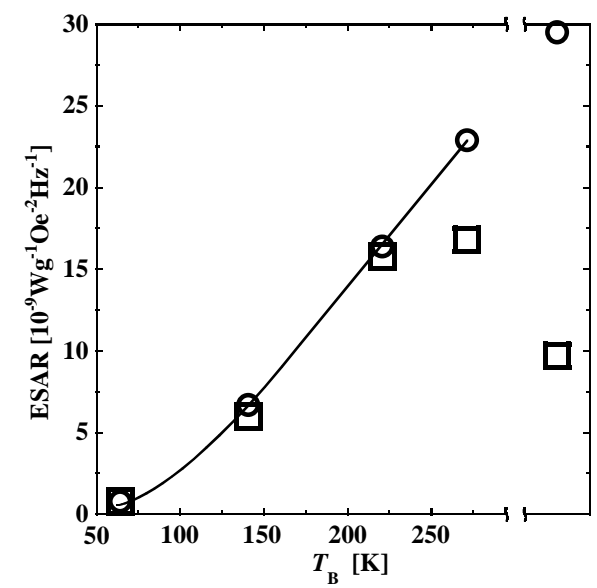

Fig. 7 Relationship between $T_{\mathrm{B}}$ and ESAR. $\mathrm{O}: \mathrm{ESAR}_{\text {low }}$, and $\square: \mathrm{ESAR}_{\mathrm{high}_{\eta}}$.

できなかった。

\section{3 発熱特性}

発熱測定の結果，得られたサンプルの ESAR を Table 1 に示す. サンプル $\mathrm{A} \sim \mathrm{C}$ では，粘度によらず発熱特性はほ ぼ一定だった。これらのサンプルは粒子径が比較的小さい ことから，Néel 緩和による発熱の寄与が大きい．そのため 粘度によらず，ほぼ一定の発熱特性を示したものと考えら れる。一方，サンプル D を PVA ハイドロゲル中に分散さ せたところ，水分散の場合よりも ESAR は $27 \%$ 低下した。 粒子径を考慮すると，サンプル D の発熱は Néel 緩和だけ でなく, Brown 緩和の寄与が存在する。このため, 高粘度 環境において Brown 緩和が抑制されたものと推察される.

一方，サンプル E の ESAR は低粘度環境では $29.5 \times 10^{-9}$ $\mathrm{Wg}^{-1} \mathrm{Oe}^{-2} \mathrm{~Hz}^{-1}$ であり，全サンプルの中で最高值を示した。 しかしながら，高粘度環境では $9.69 \times 10^{-9} \mathrm{Wg}^{-1} \mathrm{Oe}^{-2} \mathrm{~Hz}^{-1}$ と なり，低粘度環境と比較して $67 \%$ 低下した。これは，サン プル E の磁気発熱は大部分が Brown 緩和に由来すること を示唆している．本研究で作製した高粘度サンプルは，ヒ 卜腓腹筋やブタの摘出肝の剛性率，および粘性係数をどち らも上回っている ${ }^{16)}$. このことから, $\mathrm{Fe}_{3} \mathrm{O}_{4}$ ナノ粒子を生 
体組織に導入した場合でも十分な発熱が期待できる.

また, 直径 $13 \mathrm{~nm}$ 以下の $\mathrm{Fe}_{3} \mathrm{O}_{4}$ ナノ粒子では Néel 緩和 の寄与が大きく, 平均粒子径が $13 \mathrm{~nm}$ 以上の粒子では Brown 緩和の寄与が大きくなることが明らかにされた。こ れらの結果は理論発熱量(Fig. 1) と似た傾向を示している. しかし，本研究で用いた $\mathrm{Fe}_{3} \mathrm{O}_{4}$ ナノ粒子は広い粒度分布を 持っていたため, 実験で求めた ESAR は理論值よりも低い 值となった．Brown 緩和機構によって発熱する粒子，およ び ESAR の低い粒子を分離，除去することで，ESAR が高 く, かつ発熱特性が粘度に依存しない粒子だけを高効率で 回収できるものと考えられる。

Fig.7 に低粘度における発熱量 $\left(\mathrm{ESAR}_{\mathrm{low}_{\eta}}\right)$ と高粘度にお ける発熱量 $\left(\mathrm{ESAR}_{\mathrm{high}_{\eta}}\right)$ の $T_{\mathrm{B}}$ との関係を示した. $T_{\mathrm{B}}$ の上昇 に伴って $\mathrm{ESAR}_{\mathrm{low}_{\eta}}$ は増大した。一方, $\mathrm{ESAR}_{\mathrm{high}_{\eta}}$ は $T_{\mathrm{B}}$ が $220 \mathrm{~K}$ 程度までは $\mathrm{ESAR}_{\mathrm{low}_{\eta}}$ と同程度の発熱量を示し, それ 以上の温度領域では差異が生じている。これは， $T_{\mathrm{B}}$ が 220 $\mathrm{K}$ 以上の $\mathrm{Fe}_{3} \mathrm{O}_{4}$ ナノ粒子は Néel 緩和だけでなく Brown 緩 和によって発熱することを示している。また， $\operatorname{ESARhigh}_{\eta}$ は約 $270 \mathrm{~K}$ で最大となった。

T は平均粒子径に依存する一方, 粒子径の標準偏差が大 きくなると ESAR が低下する. 例えば平均粒子径 $12.5 \mathrm{~nm}$, 標準偏差 $2.9 \mathrm{~nm}$ のサンプル D では, 実験から求めた ESAR は理論值の約半分に留まっているが, サンプルの粒度分布 が狭まると, ESAR は理論值に近づくものと推察される. 本研究で用いた $\mathrm{Fe}_{3} \mathrm{O}_{4}$ ナノ粒子は粒度分布が広いため定量 的な議論は難しいが，理論発熱量と実験值は定性的に一致 していることを考慮すると, Néel 緩和で最大発熱を示す最 適な $T_{\mathrm{B}}$ の条件は約 $270 \mathrm{~K}$ であると考えられる。

\section{5. まとめ}

本研究では，平均粒子径の異なる $\mathrm{Fe}_{3} \mathrm{O}_{4}$ ナノ粒子を用い て, 磁気緩和機構と発熱量の関係を検討した. その結果, 粒子径の増大とともに発熱量は増大したが, $\mathrm{Fe}_{3} \mathrm{O}_{4}$ ナノ粒 子の平均粒子径が約 $13 \mathrm{~nm}$ 以上では Brown 緩和による発 熱の寄与が大きくなることが明らかになった。in vivo で $\mathrm{Fe}_{3} \mathrm{O}_{4}$ ナノ粒子を用いる場合，局所的な環境の影響を受け ない Néel 緩和によって発熱する粒子が適している.したが って, 印加磁場強度 $40 \mathrm{Oe}$, 周波数 $600 \mathrm{kHz}$ での $\mathrm{MFH}$ に 適した $\mathrm{Fe}_{3} \mathrm{O}_{4}$ ナノ粒子は $T_{\mathrm{B}}$ が $270 \mathrm{~K}$ 程度であり，粒子径 が約 $12 \mathrm{~nm}$ である. 発熱効率の高い $\mathrm{Fe}_{3} \mathrm{O}_{4}$ ナノ粒子を $\mathrm{MFH}$ に用いることで，投与量の低減と同時に副作用を抑制でき る期待がある. 今後, 細胞内での $\mathrm{Fe}_{3} \mathrm{O}_{4}$ ナノ粒子の発熱挙 動や血流による熱の散逸などについて検討する必要がある。

謝辞 本研究は文部科学省からの基盤研究（A） 17201021 によって行われた。また, TEM 像を撮影していただいた東 北大学 本宮憲一技術職員に, この場を借りて謝意を表する。

\section{References}

1) M. Johannsen, U. Gneveckow, L. Eckelt, A. Feussner, N. Waldöfner, R. Scholz, S. Deger, P. Wust, S. A. Loening and A. Jordan: Int. J. Hyperthermia, 21, 637 (2005).

2) K. Maier-Hauff, R. Rothe, R. Scholz, U. Gneveckow, P. Wust, B. Thiesen, A. Feussner, A. Deimling, N. Waldoefner, R. Felix, and A. Jordan: J. Neuro-Oncol., 81, 1573 (2007).

3) B. Mondovì, A. S. Santoro, R. Strom, R. Faiola, and A. R. Fanelli: Cancer, 4, 30 (1972).

4) S. Maenosono, and S. Saita: IEEE Trans. Magn., 42, 1638 (2006).

5) R. Hergt, R. Hiergeist, I. Hilger, W. A. Kaiser, Y. Lapatnikov, S. Margel, and U. Richter: J. Magn. Magn. Mat., 270, 345 (2004).
6) T. Hosono, H. Takahashi, Y. Sato, K. Tohji, and B. Jeyadevan:Water Dynamics: $4^{\text {th }}$ International Workshop, Sendai, Japan, 2006 (AIP Conference Proceedings) 898, p. 135.

7) D. H. Kim, S. H. Lee, K. H. Im, K. N. Kim, K. M. Kim, I. B. Shim, M. H. Lee, and Y.-K. Lee: Curr. Appl. Phys., 6S1, e242 (2006).

8) J.-P. Fortin, F. Gazeau, and C. Wilhelm: Eur. Biophys. J., 37, 223 (2008).

9) A. Jordan, R. Scholz, P. Wust, H. Fähling, and R. Felix: $J$. Magn. Magn. Mat., 201, 413 (1999).

10) R. Müller, R. Hergt, M. Zeisberger, and W. Gawalek: $J$. Magn. Magn. Mat., 289, 13 (2005).

11) T. Atsumi, and B. Jeyadevan: Proc. SPIE Int. Soc. Opt. Eng., 628, 5593 (2002)

12) L.-Y. Zhang, H.-C. Gu, and X.-M. Wang: J. Magn. Magn. Mat., 311, 228 (2007).

13) R. E. Rosensweig: J. Magn. Magn. Mat., 252, 370 (2002).

14) H. Sasaki, O. J. P. Perez, B. Jeyadevan, K. Tohji, A. Kasuya J. Jpn. Soc. Powder Powder Metal., 49, 2 (2002).

15) M. Ohta, A. Handa, H. Iwata, D. A. Rüfenacht, and S. Tsutsumi: Technol. Health Care, 12, 225 (2004).

16) M. Suga, K. Minato, T. Matsuda, O. Oshiro, K. Chihara, M. Ohta, S. Tsutsumi, M. Komori, T. Takahashi, J. Okamoto, and O. Takizawa: Med. Imaging Technol., 18, 769 (2000).

17) D. R. Lide: CRC Handbook of chemistry and physics 76th edition (CRC Press Inc., Boca Raton, FL, 1995).

18) B. Jeyadevan, and K. Nakatsuka: J. Magn. Magn. Mat., 149, 60 (1995)

2008 年 10 月 31 日受理， 2009 年 5 月 19 日採録 